\title{
Cerdulatinib, a novel dual SYK/JAK kinase inhibitor, has broad anti-tumor activity in both ABC and GCB types of diffuse large B cell lymphoma
}

\author{
Jiao Ma ${ }^{1}$, Wei Xing ${ }^{2}$, Greg Coffey ${ }^{3}$, Karen Dresser ${ }^{2}$, Kellie Lu ${ }^{4}$, Ailin Guo ${ }^{5}$, Gordana \\ Raca $^{6}$, Anjali Pandey ${ }^{3}$, Pamela Conley ${ }^{3}$, Hongbo $\mathbf{Y u}^{2}$, Y. Lynn Wang ${ }^{5}$ \\ ${ }^{1}$ Department of Pathology and Laboratory Medicine, Weill Cornell Medical College, New York, NY, USA \\ ${ }^{2}$ Department of Pathology, University of Massachusetts Memorial Medical Center and Medical School, Worcester, MA, USA \\ ${ }^{3}$ Department of Biology, Portola Pharmaceuticals, Inc., South San Francisco, CA, USA \\ ${ }^{4}$ University of Chicago Laboratory School, Chicago, IL, USA \\ ${ }^{5}$ Department of Pathology, Division of Genomic and Molecular Pathology, University of Chicago, Chicago, IL, USA \\ ${ }^{6}$ Department of Medicine, University of Chicago, IL, USA \\ Correspondence to: Y. Lynn Wang, e-mail: ylwang@bsd.uchicago.edu \\ Keywords: diffuse large B cell lymphoma, cerdulatinib, SYK, JAK-STAT, molecularly targeted therapy \\ Received: May 27, 2015 \\ Accepted: October 23, 2015 \\ Published: November 05, 2015
}

\section{ABSTRACT}

B-cell receptor (BCR) and JAK/STAT pathways play critical roles in diffuse large B-cell lymphoma (DLBCL). Herein, we investigated the anti-lymphoma activity of cerdulatinib, a novel compound that dually targets SYK and JAK/STAT pathways. On a tissue microarray of 62 primary DLBCL tumors, $58 \%$ expressed either phosphorylated SYK or STAT3 or both. SYK and STAT3 are also phosphorylated in a panel of eleven DLBCL cell lines although $A B C$ and GCB subtypes exhibited different JAK/STAT and BCR signaling profiles. In both $A B C$ and GCB cell lines, cerdulatinib induced apoptosis that was associated with caspase-3 and PARP cleavage. The compound also blocked G1/S transition and caused cell cycle arrest, accompanied by inhibition of RB phosphorylation and down-regulation of cyclin E. Phosphorylation of BCR components and STAT3 was sensitive to cerdulatinib in both ABC and GCB cell lines under stimulated conditions. Importantly, JAK/STAT and BCR signaling can be blocked by cerdulatinib in primary GCB and non-GCB DLBCL tumor cells that were accompanied by cell death. Our work provides mechanistic insights into the actions of cerdulatinib, suggesting that the drug has a broad anti-tumor activity in both $A B C$ and GCB DLBCL, at least in part by inhibiting SYK and JAK pathways.

\section{INTRODUCTION}

Diffuse large B-cell lymphoma (DLBCL) is the most common type of non-Hodgkin lymphoma (NHL) and accounts for approximately $40 \%$ of all NHL cases. The tumor progresses rapidly and treatment is normally initiated immediately after a patient is diagnosed with the disease. The standard chemoimmunoregimen, rituximab, cyclophosphamide, doxorubicin, vincristine and prednisone (R-CHOP), is effective in $\sim 60 \%$ of patients, but nearly $50 \%$ of patients treated with R-CHOP will eventually progress and relapse. The death rate of DLBCL remains at approximately $30 \%$. Thus, there is an urgent demand for the development of more effective therapies based on the understanding of molecular pathogenesis.

Aberrant B-cell receptor (BCR) signaling is implicated in B-cell malignancies including DLBCL. The BCR complex consists of surface immunoglobulins (sIg) that bind antigen in association with disulfide-linked heterodimer CD79A and CD79B proteins [1]. Upon antigen binding, the conformational change of SIg transduces the signal to the cytoplasmic portions of CD79A/B and results in the phosphorylation of the immunoreceptor tyrosine-based activation motif (ITAM) by SRC-family protein tyrosine kinase LYN. Phosphorylation of ITAMs then recruits cytosolic tyrosine kinase SYK and causes 
its phosphorylation and activation. SYK then triggers activation of the PI3K-AKT and BTK-PLC $\gamma 2$ pathways with the subsequent generation of inositol triphosphate $\left(\mathrm{IP}_{3}\right)$ and diacylglycerol (DAG). This event is followed by activation of multiple distal signaling pathways for B-cell activation, such as RAS-MAPK pathway, PKC activation and formation of CARD11/BCL10/MALT1 complex, and subsequent $\mathrm{NF \kappa B}$ activation [1].

The first evidence that dysregulated BCR activation is a major contributor to DLBCL pathogenesis came from gene expression profiling analysis. Based on relatedness of gene expression profiles to normal B-cell subsets, DLBCL were classified into three cell-of-origin subtypes: germinal center B-cell (GCB) subtype, activated B-cell (ABC) subtype and primary mediastinal B-cell lymphoma (PMBL) [2-5].

Subsequent studies revealed that different signaling pathways are involved in these distinct subtypes of DLBCL [6]. The main molecular and genetic abnormalities in GCB DLBCL include activation of PI3K/AKT/mTOR pathway, BCL2 translocations, and BCL6 rearrangements and overexpression, MYC rearrangements, and $\mathrm{EZH} 2$ mutations; while $\mathrm{ABC}$ DLBCL is featured with the activation of BCR, NF- $\mathrm{KB}$ and JAK-STAT pathways with associated mutations in genes including $C D 79 A / B$, CARD11, TNFAIP3 (A20) and MYD88. For PMBL DLBCL, key molecular abnormalities include CIITA translocations, amplification of REL, amplification of chromosome region 9p24 containing PD-L1, PD-L2 and JAK2 loci, and activation of NF- $\kappa$ B pathways $[3,7,8]$. These molecular subtypes are clinically relevant as patient outcomes and responses to chemoimmunotherapeutic regimens are different: GCB DLBCL has much higher response rate than ABC subtype to R-CHOP, while most of PMBL DLBCL can be cured with DA-EPOCH-R regimen [6].

Additional information regarding the molecular features of DLBCL was revealed by analysis of gene expression profiles with consensus clustering which groups lymphomas by functional relatedness of genes [9]. This analysis also identified three groups: BCR/ proliferation, OxPhos, and Host response. The BCR group is featured with high expression of SYK mRNA along with mRNA of other BCR pathway components. Concordance between the cell-of-origin and consensus clustering schemes, however, is poor. A common molecular feature identified is the increased BCR signaling in a significant fraction of DLBCL patients, ABC-DLBCL by cell-oforigin scheme and BCR-DLBCL by consensus clustering scheme. These studies provide a strong rationale to target BCR signaling in DLBCL.

Previously, several groups including ours have explored the potential of inhibiting BCR pathways in DLBCL cell lines and primary tumor cells [10-14]. We showed that targeting LYN [12] or SYK [13] inhibits BCR signaling and cell proliferation in a subset of DLBCL. Shipp's group further demonstrated the cells responding to SYK inhibition carry the BCR signature with either high or low NFkB activity [14].
From a clinical perspective, targeting the BCR pathway, however, has met with limited success in DLBCL patients compared to patients with other types of NHL and chronic lymphocytic leukemia (CLL). Fostamatinib, a SYK inhibitor, produced an objective response in 5 of $23(22 \%)$ relapsed/refractory $(R / R)$ DLBCL patients in a phase I/II study [15]. Enzastaurin, a PKC $\beta$ inhibitor, produced 3 complete responses and 1 stable disease in $55 \mathrm{R} / \mathrm{R}$ patients [16]. As to ibrutinib, a BTK inhibitor, in a phase II study of $80 \mathrm{R} / \mathrm{R}$ DLBCL, only $37 \% \mathrm{ABC}$ and $5 \% \mathrm{GCB}$ subtypes were responsive and the response rate of all DLBCL tumors was 19\% [17]. Genetic analysis revealed that mutation in MYD88 can nullify the effect of BCR signaling blockade via Toll-likereceptor (TLR) signaling pathway leading to downstream $\mathrm{NF}-\kappa \mathrm{B}$ activation [17]. In addition, gain-of-function mutations in downstream CARD11 and A20 can drive the constitutive activation of the NF- $\mathrm{kB}$ pathway irrespective of upstream BTK blockade. The complexity of molecular and genomic alterations in DLBCL has severely limited the effectiveness of single-targeted therapy, thus the combination of targeted agents or multi-targeted agents have greater appeals in improving treatment response in DLBCL.

The Janus kinase and Signal Transducer and Activator of Transcription (JAK-STAT) pathway represents another important signaling pathway in the pathogenesis of DLBCL. One mechanism of STAT3 activation in ABC DLBCL (or non-GCB) has been defined. STAT3 is both overexpressed and activated primarily as a function of autocrine secretion of IL-6/IL-10 by tumor cells [18], a survival mechanism that can be promoted in the context of mutations that drive NF- $\mathrm{KB}$ activation and subsequent NF-KB-mediated cytokine expression [19]. In addition, it is possible that non-tumor cells of the tumor microenvironment promote malignant cell survival in part via paracrine cytokine secretion [20,21]. Clinically, STAT3 activation, as reflected by STAT3 phosphorylation has been associated with worse survival in patients treated with R-CHOP [22]. In vitro inhibition of STAT3 activity with either JAK inhibitors or STAT3 knockdown results in decreased cell proliferation and increased apoptosis in $\mathrm{ABC}$ tumor cell lines $[18,23]$. Moreover, early clinical studies suggest that targeting JAK/STAT pathways using small molecule JAK inhibition [24], STAT3 knock down (Hong DS, et al. 2013 ASCO annual meeting abstract \#8523), or a neutralizing antibody specific for IL-6 [25] may be beneficial for patients with B-cell malignancies.

Thus, literature evidence provides a strong rationale to target both BCR and JAK-STAT pathway in DLBCL. Cerdulatinib (previously known as PRT062070) is a novel orally available small-molecule ATP-competitive inhibitor that demonstrates inhibition of SYK, JAK1, JAK2, JAK3, and TYK2 in a biochemical assay [26] (Table 1). However, at the cellular level, cerdulatinib demonstrates specificity towards JAK1/JAK3 and TYK2, but not JAK2-mediated responses. The specificity of cerdulatinib was also 
Table 1: Activity of cerdulatinib against selected kinases, and their expression in normal LN and lymphoma tissues

\begin{tabular}{|c|c|c|c|}
\hline Kinase & IC50 (nM) & Expression in normal lymph node* & Expression in primary lymphoma tissue* \\
\hline TYK2 & 0.5 & ND & Mostly ND \\
\hline MST1 & 4 & ND & Mostly ND \\
\hline ARK5 & 4 & ND-Low & ND \\
\hline MLK1 & 5 & ND & ND \\
\hline FMS & 5 & N/A & N/A \\
\hline AMPK & 6 & Medium & Medium to High \\
\hline JAK2 & 6 & Medium to High & Mostly High \\
\hline JAK3 & 8 & N/A & N/A \\
\hline TBK1 & 10 & Low to Medium & Low to Medium \\
\hline MARK1 & 10 & Low to Medium & ND \\
\hline JAK1 & 12 & Medium & Low to Medium \\
\hline PAR1B- $\alpha$ & 13 & N/A & N/A \\
\hline TSSK & 14 & N/A & N/A \\
\hline MST2 & 15 & ND & ND \\
\hline GCK & 18 & Low & Mostly Low \\
\hline JNK3 & 18 & ND & ND \\
\hline RSK2 & 20 & N/A & N/A \\
\hline RSK4 & 28 & Medium to High & Mostly Medium \\
\hline SYK & 32 & High & Mostly High \\
\hline CHK1 & 42 & ND & ND \\
\hline FLT4 & 51 & N/A & N/A \\
\hline FLT3 & 90 & Medium to High & Mostly High \\
\hline RET & 105 & Low to Medium & Mostly ND \\
\hline ITK & 194 & N/A & N/A \\
\hline
\end{tabular}

ND: Not detected. N/A: Not Available.

${ }^{*}$ Tissue microarray data adapted from the human protein atlas website at: http://www.proteinatlas.org. $\mathrm{IC}_{50}$ data were derived from Coffey G, et al. [26].

demonstrated by its lack of inhibition of $\mathrm{T}$ cell receptor signaling or protein kinase $\mathrm{C}$ signaling in whole blood [26]. In animal models, the agent reduces inflammation in a rat model of autoimmune disease, and blocks B-cell activation and alleviates splenomegaly induced by chronic BCR stimulation in mice [26]. Notably, in primary CLL cells with the $\mathrm{BTK}^{\mathrm{C} 481 \mathrm{~S}}$ mutation, cerdulatinib is able to overcome ibrutinib resistance by completely blocking the proliferation of the resistant cells [27-29]. Cerdulatinib is currently under investigation as a single orally administered agent in a dose escalation study in relapsed/ refractory CLL and B cell non-Hodgkin lymphoma (NHL; NCT01994382). Initial clinical results have demonstrated good tolerability, significant inhibition of SYK and JAK, and greater than $50 \%$ target tumor reductions in patients with CLL and NHL (Flinn I, et al. 2015 ASCO annual meeting Abstract \#8531). Herein, we further characterize antitumor activities of cerdulatinib in subtypes of DLBCL cell lines and primary tumor cells. The results suggest cerdulatinib exerts broad anti-tumor activity in both $A B C$ and GCB DLBCL including cells with resistance to BCRtargeted therapy. 


\section{RESULTS}

\section{STAT3 and SYK are active in an array of primary DLBCL tissues of both GCB and non-GCB subtypes}

To determine whether simultaneous targeting of both JAK/STAT and SYK is relevant in DLBCL, we examined the expression of p-STAT3 (Y705) and p-SYK (Y525/526) on a tissue microarray of 62 DLBCL primary tumors, including 41 germinal center-like (GCB) and 21 non-germinal-center-like (non-GCB) tumors classified using Han's algorithm [30] (Figure 1). p-STAT3 exhibits a characteristic nuclear staining pattern in DLBCL cases (Figure 1A). Patterns other than nuclear were excluded as positive staining. p-STAT3 staining in tonsil is included as control (Figure 1 A-d). A total of $26(26 / 62,42 \%)$ stained positive for nuclear p-STAT3; 16 were GCB type $(16 / 41,39 \%)$ and 10 were non-GCB type $(10 / 21,48 \%$, Figure 1B). p-SYK expression was detected in 29 (29/62, $47 \%$ ) cases with a characteristic peri-membrane staining pattern (Figures 1A and 1B). Patterns other than perimembrane were excluded as positive staining. p-SYK staining in tonsil is included as control (Figure 1A-h). While occasionally germinal centers were found to contain a few scattered p-SYK positive cells, most of the germinal centers in the tonsil are completely negative for p-SYK. Of these 29 p-SYK positive cases, 17 were GCB type (17/41, $41 \%)$ and 12 were non-GCB type (12/21, 57\%, Figure 1B). Interestingly, there are 19 cases (19/62, 31\%) among the total 62 cases with reactivity for both p-SYK and p-STAT3, of which, 11 were GCB type $(11 / 41,27 \%)$ and 8 were non-GCB type $(8 / 21,38 \%$, See Figure 1B for case numbers and Figure $1 \mathrm{C}$ for percentage breakdown). These data are consistent with the single stain results published previously on p-STAT3 by Huang et al [22] and on p-SYK by our group [13]. Together, these findings demonstrated that SYK and STAT3 are active in a significant number of DLBCL cases (Figure 1C).

\section{STAT3 and SYK are active in a panel of DLBCL cell lines of both GCB and ABC subtypes}

We then determined the basal expression levels of BCR signaling and JAK/STAT signaling molecules and their phosphorylation status in a panel of GCB and ABC DLBCL cell lines using immunoblotting analysis. The cell lines studied include six GCB cell lines: OCILY1 (LY1), OCI-LY4 (LY4), OCI-LY8 (LY8), OCI-LY18 (LY18), SUDHL6 (DHL6) and VAL, and 5 ABC cell lines: OCI-LY3 (LY3), SUDHL2 (DHL2), HBL1, U2932 and OCI-LY10 (LY10). As shown in Figure 2, three of the five $A B C$ cell lines exhibited very high levels of total and phosphorylated STAT3 at both Y705 and S727 sites (LY3, DHL2 and LY10). In contrast, little total or phosphorylated STAT3 proteins were detected in the six GCB cell lines. The immunoblotting also revealed some interesting findings regarding all the GCB and HBL1 cell lines. Although the expression and phosphorylation of SYK, PLC $\gamma 2$ and ERK and total AKT levels are variable among the cell lines, in general, all GCB appear to express higher levels of p-SYK, p-PLC $\gamma 2$ (at both Y759 and Y1217) and p-AKT suggesting downstream BCR activity is more active in these cell lines. Among five $\mathrm{ABC}$ cell lines, HBL1 cell line appears to be the only one that expresses high levels of p-PLC $\gamma 2$ (Figure 2). Taken together with Figure 1, active forms of SYK and JAK are expressed in a wider range of DLBCL tumors than each of the single molecule alone.

\section{Both $A B C$ and GCB subtypes of DLBCL are sensitive to dual SYK/JAK inhibition with cerdulatinib}

Cerdulatinib is an orally available ATP-competitive small molecule kinase inhibitor currently in clinical development for the treatment of B-cell malignancies (NCT01994382). Early clinical results (Flinn I, et al. 2014 ASCO annual meeting Abstract \#2619) suggest that high level of SYK and JAK inhibition is achieved in treated patients, with an acceptable safety profile. In biochemical assays, cerdulatinib demonstrated inhibitory activity against 24 kinases with $\mathrm{IC}_{50}$ 's $<200 \mathrm{nM}$ (Table 1). Most of the kinases affected by cerdulatinib are not expressed at all, or expressed at very low levels in normal lymph nodes and primary lymphoma tissues. Seven of these affected kinases are notably expressed including AMPK, JAK2, TBK1, JAK1, RSK4, SYK, and FLT3 (Bold in Table 1). Cerdulatinib inhibits SYK and JAK1 with $\mathrm{IC}_{50}$ 's of $32 \mathrm{nM}$ and $12 \mathrm{nM}$, respectively. A recent publication detailing the translation of biochemical assays to cellular potency and selectivity revealed that cerdulatinib principally acted as a SYK, JAK1/3, and TYK2 inhibitor, lacking cellular activity against JAK2, against the SRC family members LCK and LYN, as well as the structural homolog ZAP70 [26]. Potency against AMPK, TBK1, RSK family members, and FLT3 has not been determined in cellular assays.

We next investigated the activity of cerdulatinib in the panel of DLBCL cell lines. A cell-based MTT assay that reflects cellular metabolic activity was performed at $72 \mathrm{~h}$ following treatment with cerdulatinib at varying concentrations (Figure 3A). All cell lines demonstrated sensitivity to cerdulatinib with $\mathrm{IC}_{50}$ at or below $\sim 2 \mu \mathrm{M}$ (data compiled in Figure 3B). Notably, ABC cell lines with relatively higher total and phosphorylated STAT3 (Figure 2) displayed good sensitivity to the drug with $\mathrm{IC}_{50}$ ranging from 0.29 to $1.80 \mu \mathrm{M}$ (Figure 3B). Of these $\mathrm{ABC}$ cell lines, LY3 and DHL2 were insensitive to a SYK selective inhibitor, PRT060318, as demonstrated 
A
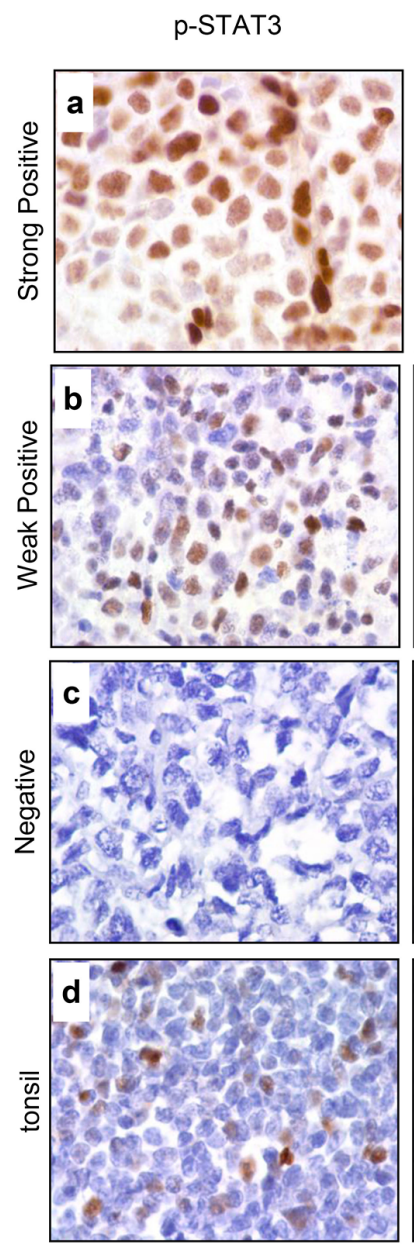

p-SYK
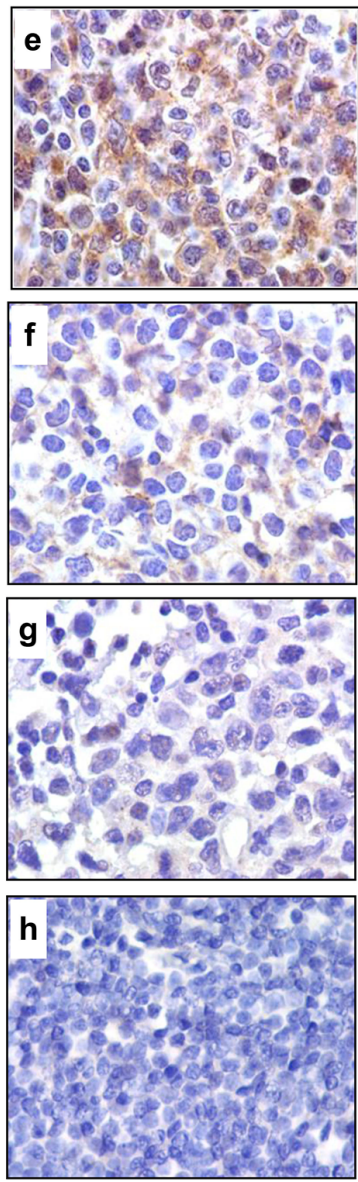

C
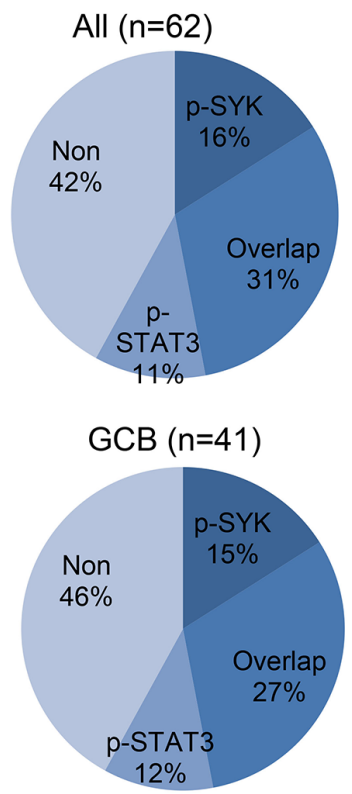

Non-GCB $(n=21)$

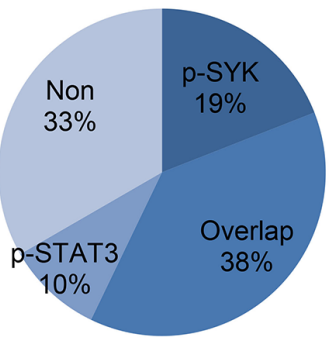

B

\begin{tabular}{|c|c|c|c|c|c|}
\hline All & p-STAT3 & Overlap & p-SYK & Non & Total \\
\hline \multirow{3}{*}{$\begin{array}{l}p \text {-STAT3 subtotal } \\
p \text {-SYK subtotal }\end{array}$} & 7 & 19 & 10 & 26 & 62 \\
\hline & & 26 & & & \\
\hline & & 29 & & & \\
\hline \multirow[t]{2}{*}{ GCB } & p-STAT3 & Overlap & p-SYK & Non & Total \\
\hline & 5 & 11 & 6 & 19 & 41 \\
\hline \multirow{2}{*}{$\begin{array}{l}p \text {-STAT3 subtotal } \\
p \text {-SYK subtotal }\end{array}$} & & 16 & & & \\
\hline & & 17 & & & \\
\hline \multirow[t]{2}{*}{ non-GCB } & p-STAT3 & Overlap & p-SYK & Non & Total \\
\hline & 2 & 8 & 4 & 7 & 21 \\
\hline \multirow{2}{*}{$\begin{array}{l}p \text {-STAT3 subtotal } \\
p \text {-SYK subtotal }\end{array}$} & & 10 & & & \\
\hline & & 12 & & & \\
\hline
\end{tabular}

Figure 1: Expression of p-STAT3 (Y705) and p-SYK (Y525/526) in normal tonsil and primary DLBCL tissues on tissue microarray. A. Expression of p-STAT3 (a-d) and p-SYK (e-h) was examined by immunohistochemistry on paraffin-embedded sections from DLBCLs (a-c and e-g) and normal tonsil tissue ( $\mathrm{d}$ and $\mathrm{h}$ ). a. A representative example of strongly positive p-STAT3 staining $(60-90 \%$ lymphoma cells). b. A representative example of weakly positive p-STAT3 staining (30-50\% lymphoma cells). c. A representative example of negative p-STAT3 staining ( $<30 \%$ lymphoma cells). d. Basal level of p-STAT3 expression in normal tonsil tissue with scattered positive cells in germinal center. e. A representative example of strongly positive p-SYK staining (60-90\% lymphoma cells). f. A representative example of weakly positive p-SYK staining (30-50\% lymphoma cells). g. A representative example of negative p-SYK staining $(<30 \%$ lymphoma cells). h. Absence of p-SYK positivity in normal tonsil tissue. (a-h, x1,000). B. Table showing the number breakdown of p-SYK and p-STAT3 staining in all, GCB or non-GCB cases. C. Pie charts showing the percent breakdown of p-SYK and p-STAT3 staining in all, GCB or non-GCB cases. 
in our previous study [13]. LY4, a GCB cell line, was also resistant to the selective SYK inhibition due to lack of surface immunoglobulins [13]. The cell line was, however, sensitive to dual inhibition by cerdulatinib with an $\mathrm{IC}_{50}$ of $2.1 \mu \mathrm{M}$. Early clinical results suggest that these concentrations can be safely achieved in the plasma of treated patients (Flinn I, et al. 2014 ASCO annual meeting Abstract \#2619). Overall, the results demonstrate potent and broad activity of cerdulatinib in DLBCL cell lines. Sensitivity to cerdulatinib was confirmed in an independent cell growth assay (Figure 3C) utilizing two GCB (SUDHL6 and LY18) and three ABC (HBL1, SUDHL2 and LY3) cell lines, which were characterized further below.

\section{Cerdulatinib induces apoptosis in both GCB and} ABC subtypes of DLBCL cell lines via caspase 3 and PARP cleavage

The effects of cerdulatinib on cellular metabolism (MTT) can result from either cell death or cell cycle inhibition or both. We therefore analyzed the effects of cerdulatinib on DLBCL cell viability. Using annexin V

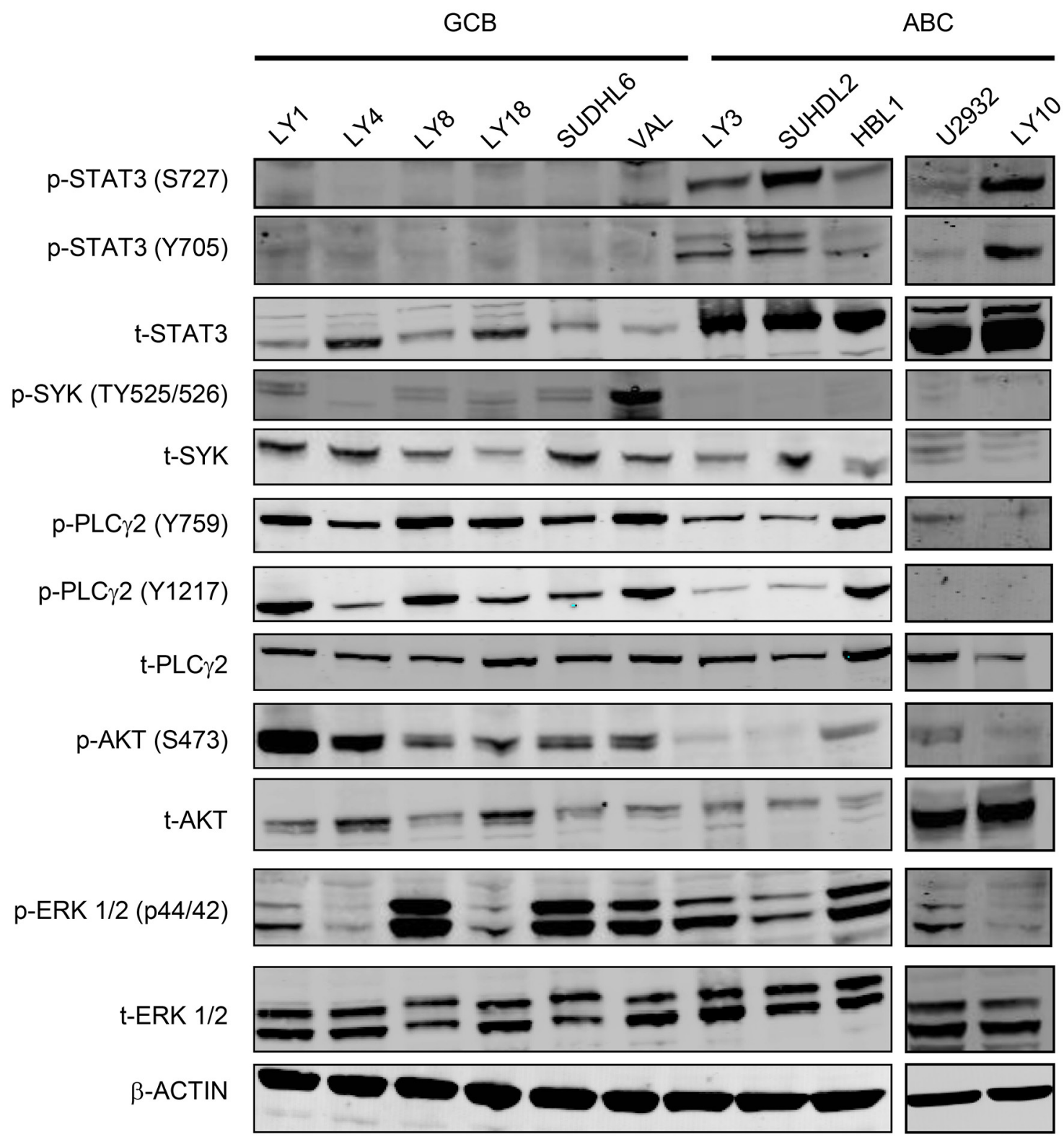

Figure 2: Distinct signaling pathways in GCB-DLBCL vs ABC-DLBCL cell lines. Western blotting analysis of the basal levels of total and phosphorylated STAT3, SYK, PLC $\gamma 2$, AKT and ERK in GCB and ABC DLBCL cell lines. Phosphorylated residues for each protein are indicated. $\beta$-actin was included as a loading control. 
A
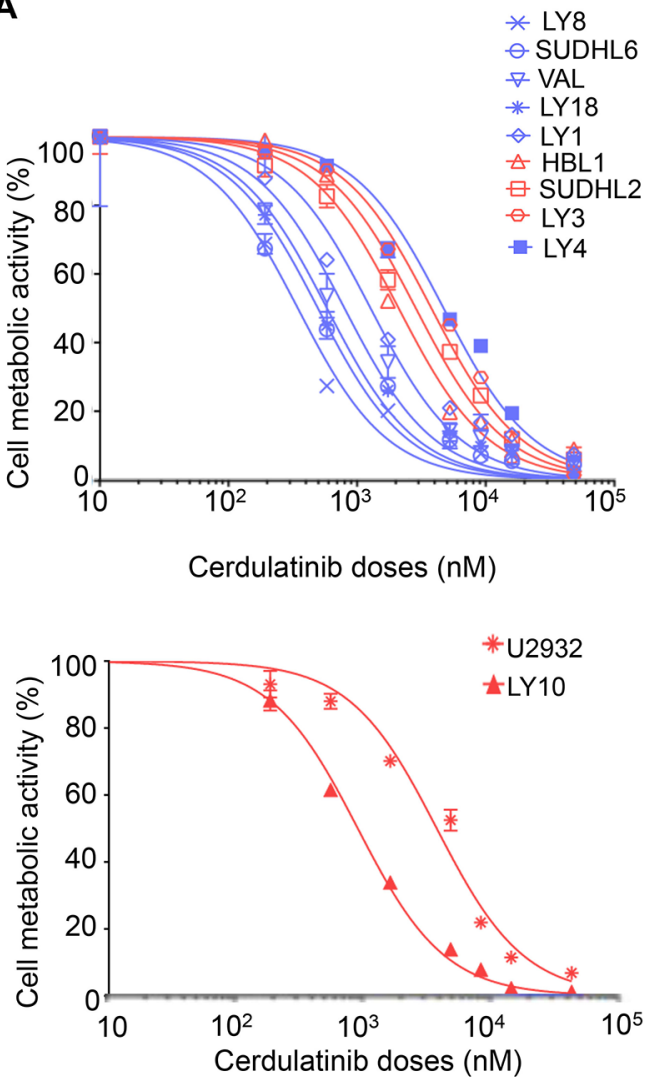

B

\begin{tabular}{|c|c|}
\hline & Cerdulatinib $(\boldsymbol{\mu M})$ \\
\hline LY8 & 0.05 \\
\hline SUDHL6 & 0.10 \\
\hline VAL & 0.13 \\
\hline LY18 & 0.16 \\
\hline LY1 & 0.27 \\
\hline LY10 & 0.29 \\
\hline HBL1 & 0.54 \\
\hline SUDHL2 & 0.98 \\
\hline LY3 & 1.66 \\
\hline U2932 & 1.80 \\
\hline LY4 & 2.10 \\
\hline
\end{tabular}

C
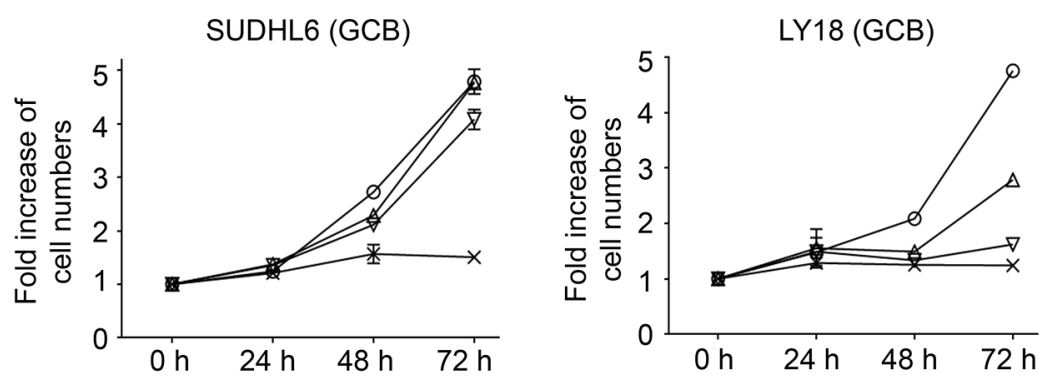

$\theta$ UT

$\triangle 0.625 \mu \mathrm{M}$

$\forall 2.5 \mu \mathrm{M}$

$* 10 \mu \mathrm{M}$

HBL1 (ABC)
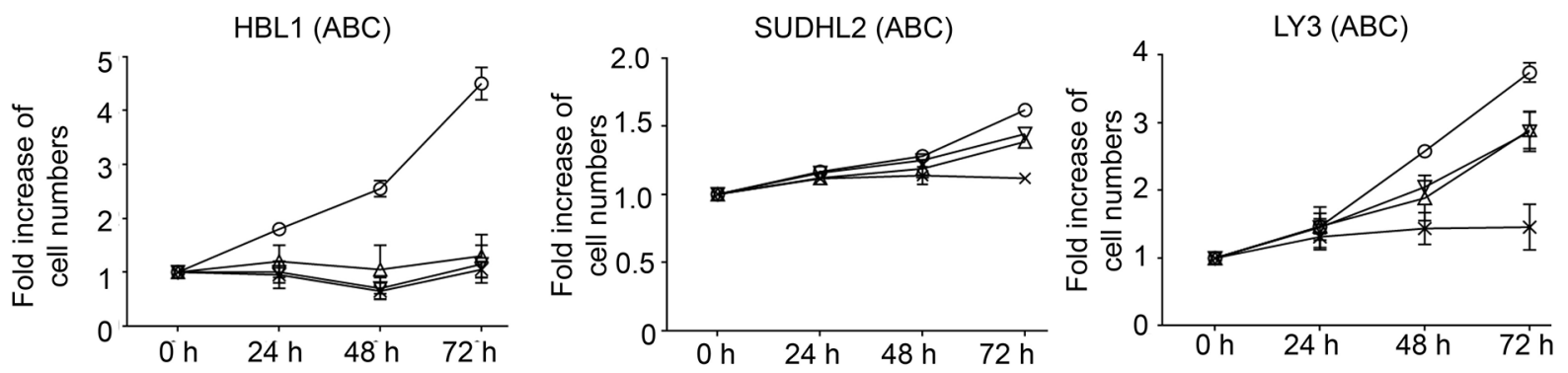

Figure 3: Both ABC and GCB subtypes of DLBCL are sensitive to dual SYK/JAK inhibition with cerdulatinib. A. DLBCL cell lines were treated with various concentrations of cerdulatinib for $72 \mathrm{~h}$ followed by MTT assay. GCB are highlighted in blue and $\mathrm{ABC}$ in red. B. $\mathrm{IC}_{50}$ values were calculated using GraphPad Prism 5 software (GraphPad, La Jolla, CA). C. DLBCL cell lines were treated with indicated concentrations of cerdulatinib for up to $72 \mathrm{~h}$. Cell numbers were determined at indicated time points and normalized to vehicle treated control. Error bars represent the standard error of the mean (SEM) from three independent experiments. 
and 7-AAD double staining, we demonstrated that with the exception of LY18, viability of all cell lines was reduced by cerdulatinib treatment in a concentration- and time-dependent manner (Figure 4A). Apoptosis induction with increasing concentrations of cerdulatinib in the four responding cell lines was accompanied by both PARP and caspase 3 cleavage whereas little changes were observed in LY18 (Figure 4B).

\section{Cell cycle arrest by cerdulatinib is associated with inhibition of RB phosphorylation and down-regulation of cyclin $E$}

After establishing apoptosis induction as one of the drug's actions, we then studied the effect of cerdulatinib on cell cycle progression using BrdU incorporation. As shown in Figure 5A, DHL6, LY18 and HBL1 appeared

A
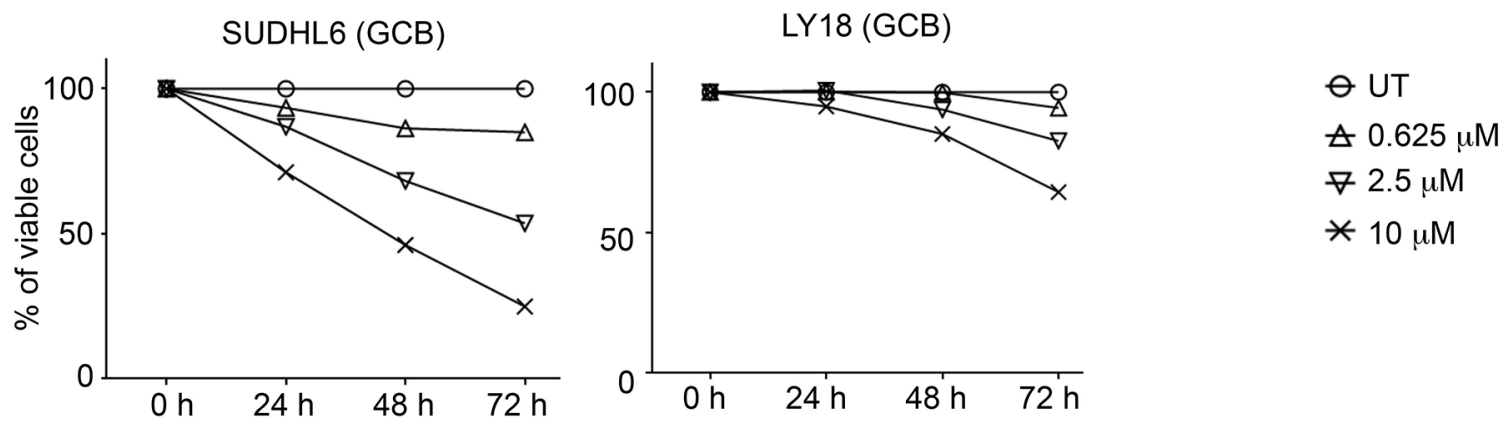

HBL1 (ABC)
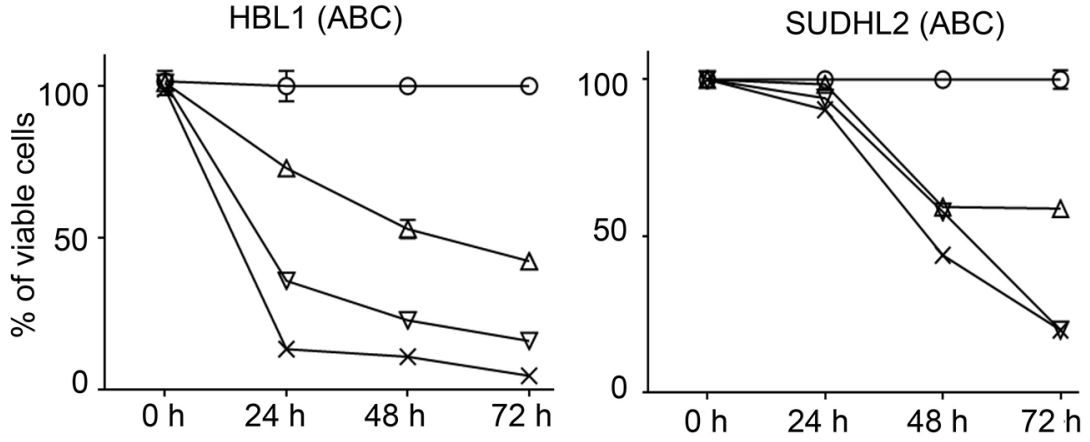

LY3 (ABC)

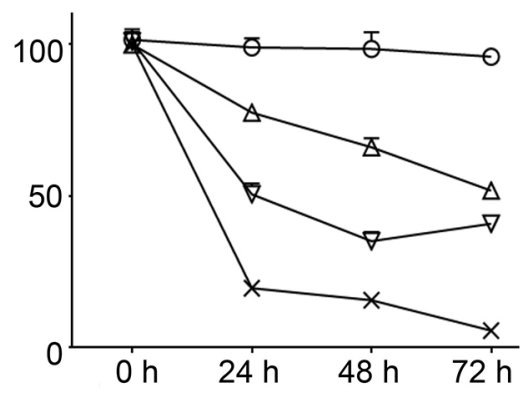

GCB

$A B C$

B
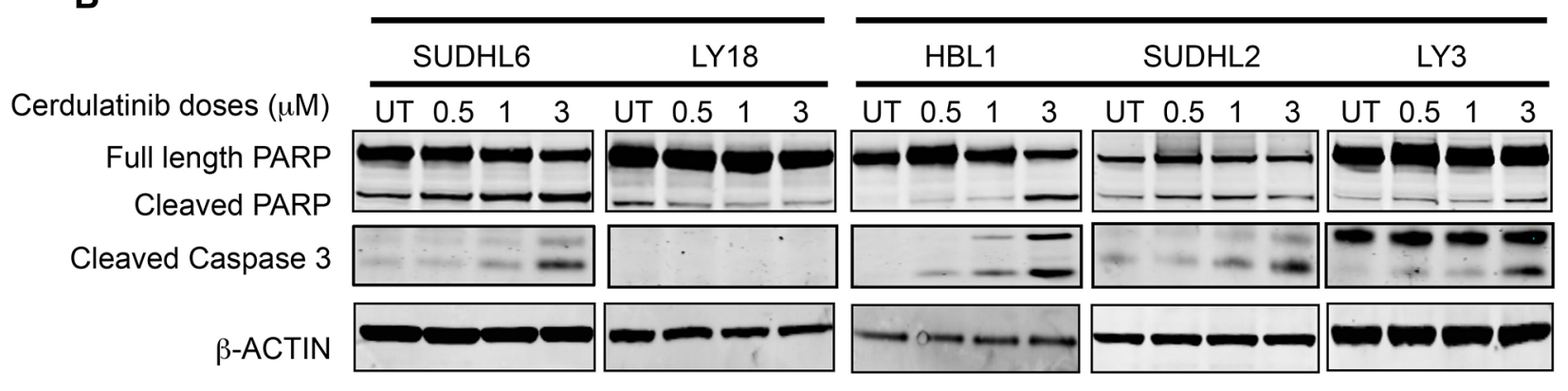

Figure 4: Cerdulatinib induces apoptosis in both GCB and ABC subtypes of DLBCL cell lines via caspase 3 and PARP cleavage. A. Viability of DLBCL cells treated with various doses of cerdulatinib for up to $72 \mathrm{~h}$. Cells were collected at indicated time points, and stained with annexin $\mathrm{V}$ and 7-AAD. Cell viability was measured using flow cytometry, and shown as the percent viable cells (annexin V-/7-AAD-) relative to vehicle treated control. Error bars represent the SEM from three independent experiments. B. DLBCL cells were treated with indicated doses of cerdulatinib for $48 \mathrm{~h}$. Western blotting was performed using antibodies against PARP and caspase 3. $\beta$-actin was included as a normalization control. 
to be particularly sensitive to cerdulatinib treatment with significant dose-dependent reduction in S phase fraction, while the effects of the drug on DHL2 and LY3 were modest in comparison. The dose-dependent S-phase reductions caused by the drug are largely consistent with its inhibition of phosphorylated RB and with decrease in cyclin E expression (Figure 5B): While bigger changes were observed in HBL1, SUDHL6 and LY18, little or no changes were observed in SUDHL2 and LY3. Collectively, our data on apoptosis (Figure 4) and on cell cycle progression (Figure 5) suggests that cerdulatinib achieves its inhibitory effects in different DLBCL cell lines (Figure 3A and 3B, MTT assay) via different cellular processes, either induction of apoptosis or induction of cell cycle arrest.

\section{Cerdulatinib induces apoptosis and cell cycle arrest in BCR-stimulated DLBCL cells}

Since the BCR pathway may be chronically active in many DLBCL, we next examined the capability of cerdulatinib to inhibit cell cycle and induce apoptosis under the condition of BCR stimulation. Figure 6A shows that BCR stimulation with anti-IgM and anti-IgG drove more cells into S-phase in all five cell lines regardless of subtypes and these stimulated tumor cells were sensitive to cerdulatinib treatment. Similarly, the viability of stimulated DLBCL cells were reduced by cerdulatinib in all cell lines tested (Figure 6B). Taken together with the results under the resting conditions (Figures 4A and 5A), we conclude that cerdulatinib achieves its anti-tumor effects in ABC and GCB DLBCL cell lines via induction of apoptosis and cell cycle arrest with or without external stimulation.

\section{Cerdulatinib blocks JAK/STAT and BCR signaling in both $\mathrm{ABC}$ and GCB DLBCL cell lines}

To determine whether cerdulatinib inhibits BCR and JAK-STAT signaling pathways, we first measured the phosphorylation of SYK, PLC $\gamma 2$, AKT and ERK in

A

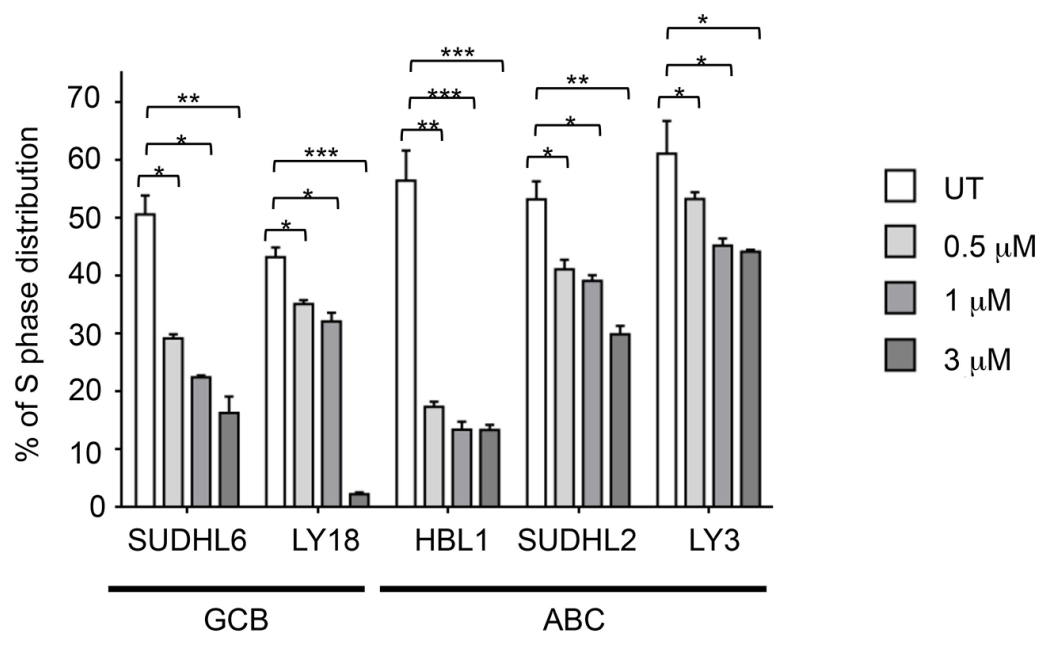

B

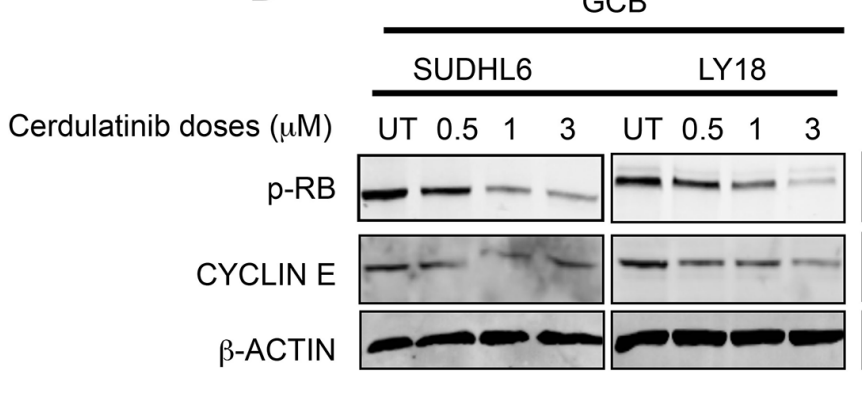

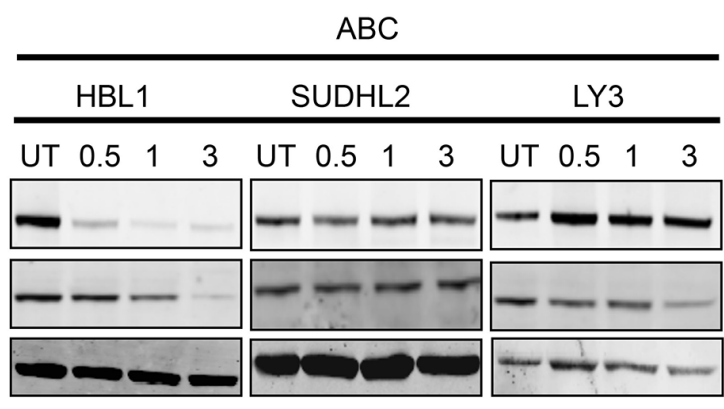

Figure 5: Cerdulatinib blocks cell cycle in both $A B C$ and GCB subtypes of DLBCL via inhibition of RB phosphorylation and down-regulation of cyclin E. A. DLBCL cells were treated with indicated doses of cerdulatinib for $48 \mathrm{~h}$. Cells were labeled with $10 \mu \mathrm{M}$ BrdU for $2 \mathrm{~h}$, followed by double staining with BrdU antibody and 7-AAD prior to flow cytometry analysis. Percentage of cells at S phase was statistically analyzed using one-way ANOVA test and graphed using prism 5 GraphPad. Error bars represent the SEM from three independent experiments. ${ }^{*} p<0.05$; ${ }^{*} p<0.01 ; * * p<0.005$. B. DLBCL cells were treated with indicated concentrations of cerdulatinib. The whole cell lysates were prepared at $48 \mathrm{~h}$ following treatment. Immunoblotting was performed using p-RB and cyclin E antibodies. $\beta$-actin was included as a loading control. 
BCR-stimulated DLBCL cells treated with or without cerdulatinib (Figure 7A). Immunoblotting analyses revealed a significant reduction of p-SYK in all cell lines, reduction of p-PLC $\gamma 2$ in the two GCB cell lines (DHL6 and LY18), reduction of p-AKT in four of the five cell lines (except DHL2) and reduction of p-ERK in two of the five cell lines (DHL6 and LY3). When analyzing data by individual cell lines, reduction in protein phosphorylation was observed: SYK, PLC $\gamma 2$, AKT and ERK in DHL6; SYK, PLC $\gamma 2$ and AKT in LY18; SYK and AKT in HBL1, SYK in DHL2; and SYK, AKT and ERK in LY3. Thus, despite the variability, at least one signaling component of the BCR pathway was effectively inhibited by cerdulatinib in each individual cell line.

We also determined whether cerdulatinib inhibits the JAK-STAT signaling pathways under the condition of

A

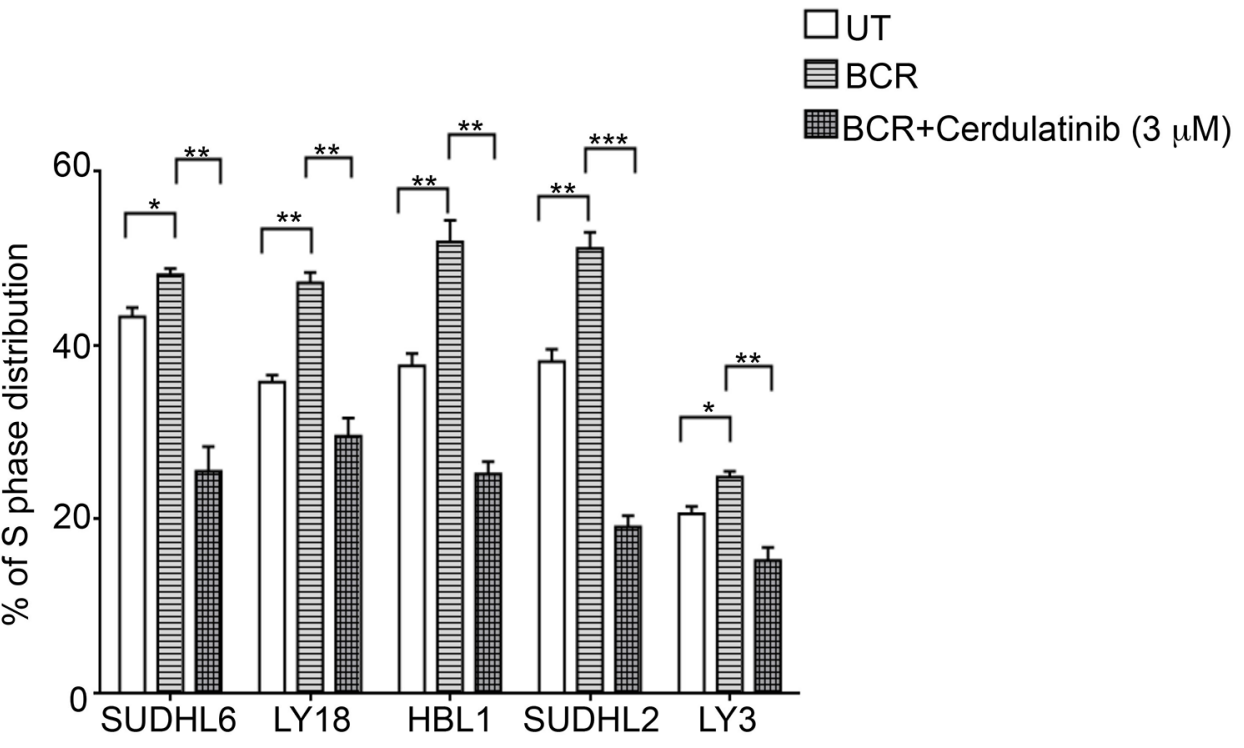

B

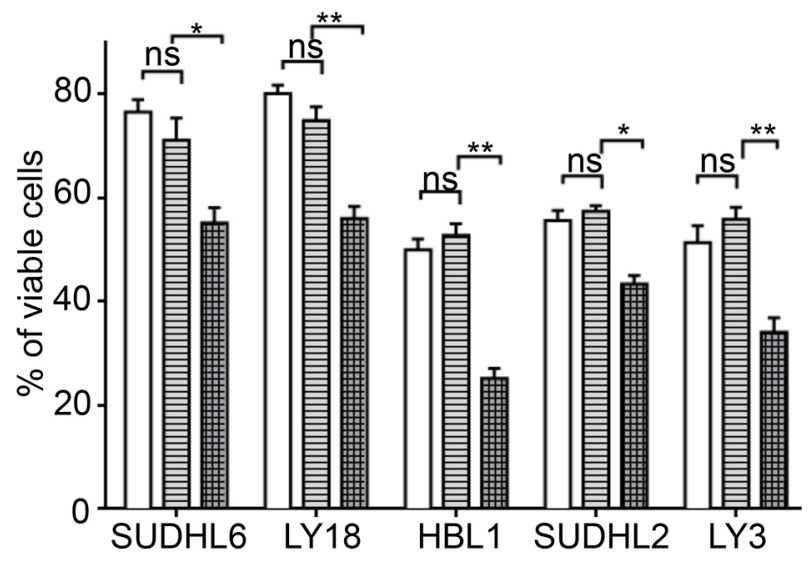

Figure 6: Cerdulatinib induces cell cycle arrest and apoptosis under the condition of BCR stimulation in all DLBCL cell lines. A. DLBCL cells were treated with $3 \mu \mathrm{M}$ of cerdulatinib for $48 \mathrm{~h}$ and labeled with $10 \mu \mathrm{M}$ BrdU for $2 \mathrm{~h}$, followed by double staining with BrdU antibody and 7-AAD prior to flow cytometry analysis. B. Following $48 \mathrm{hr}$ drug treatment, cells were stained with annexin V and 7-AAD. Percentage of viable cell relative to vehicle control or cells at S phase was statistically analyzed using one-way ANOVA test and graphed using prism 5 GraphPad. Error bars represent the SEM from three independent experiments. ${ }^{*} p<0.05 ; * * p<$ $0.01 ; * * * p<0.001$ 
cytokine stimulation. Cells stimulated with IL-6 and IL-10 were treated with cerdulatinib or vehicle, phosphorylation of STAT3 at Y705 was measured. As shown in Figure $7 \mathrm{~B}$, cytokine stimulated cells expressed very high levels of p-STAT3 regardless of subtype designation. Addition of cerdulatinib completely blocked this phosphorylation event to a level that goes below the detection level. Thus, we conclude that modulation of both BCR and JAK-STAT signaling pathways by cerdulatinib correlated with its cellular toxicity in terms of cell survival and proliferation (Figure 6).

\section{Cerdulatinib induces cell death in primary human DLBCL samples}

To confirm whether data obtained with the cell lines are reproducible with primary patient tumors, we tested several human DLBCL samples, including 3 GCB, 2 non-
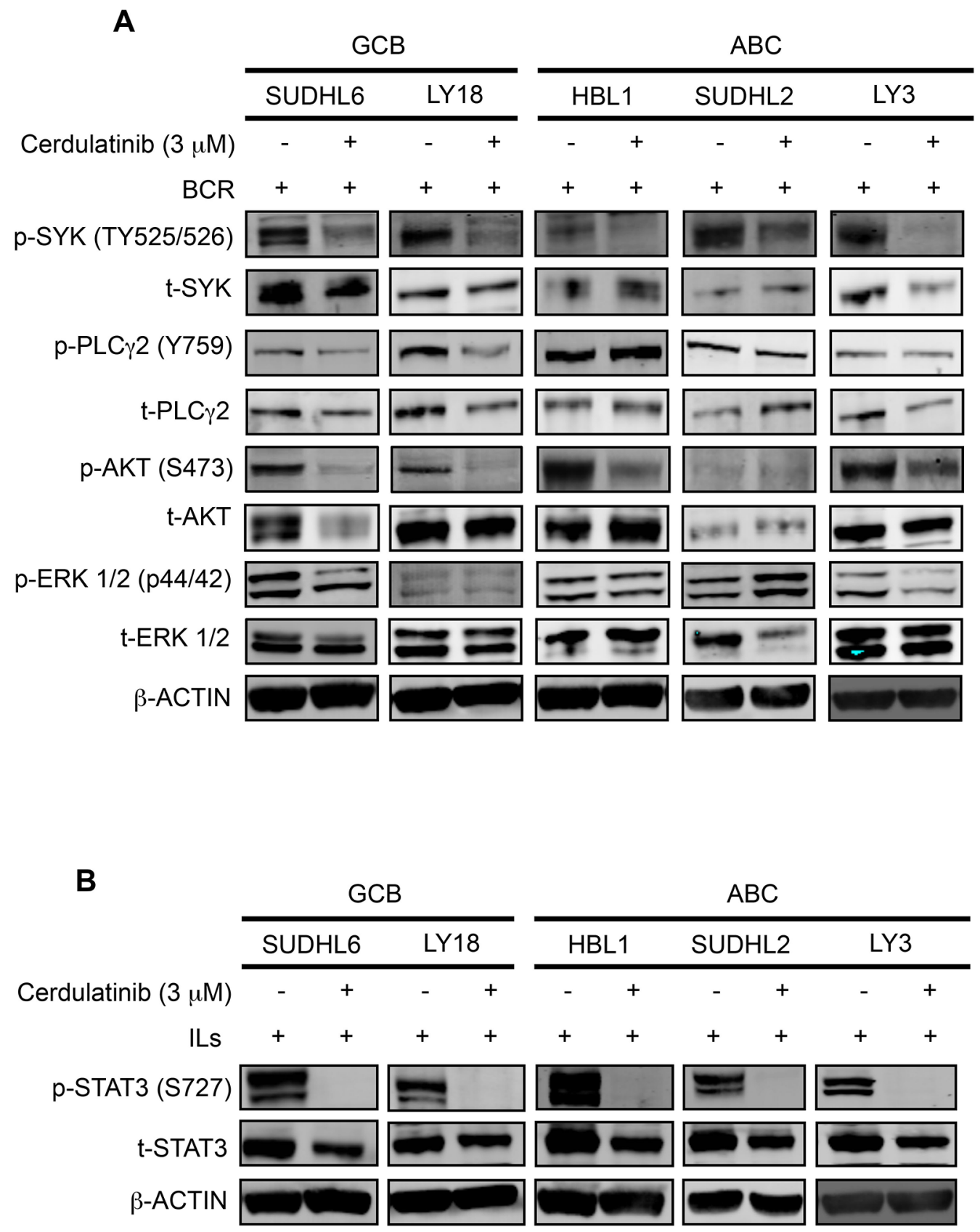

Figure 7: Cerdulatinib blocks JAK/STAT and BCR signaling in both ABC and GCB DLBCL cell lines. DLBCL cells were treated with $3 \mu \mathrm{M}$ of cerdulatinib for $30 \mathrm{~min}$, and then stimulated with either anti IgM/IgG or IL6/IL10 for $24 \mathrm{~h}$ before cell collection and lysate preparation. Immunoblotting analysis of A. p-SYK, p-PLC $\gamma 2$, p-AKT, p-ERK expressions and B. p-STAT3 expression in selected DLBCL cell lines. $\beta$-actin was included as a loading control. 
GCB and one unclassified (patient information shown in Supplemental Table 1), for their apoptotic response to $0.5 \mu \mathrm{M}$ and $1 \mu \mathrm{M}$ cerdulatinib. As shown in Figure $8 \mathrm{~A}$, all primary DLBCL cells responded to cerdulatinib in a concentration-dependent manner with variable sensitivities.

We next studied the inhibition of p-STAT3, p-ERK and $\mathrm{p}-\mathrm{AKT}$ in response to cerdulatinib treatment in these primary patient cells stimulated with anti-BCR. Phosphoflow assay demonstrated a marked and simultaneous down-regulation of p-STAT3, p-AKT and p-ERK in response to increasing concentrations of cerdulatinib in all six primary DLBCL cells regardless of their subtype designation (Figures 8B, 8C and 8D), but inhibition of the individual protein phosphorylation was highly variable among these primary samples. For instance, DLBCL3 showed no significant inhibition in p-STAT3 in response to increasing concentrations of cerdulatinib, presumably due to its very low baseline p-STAT3 level in untreated cells compared to the other patient samples (Figure 8B). DLBCL1 and DLBCL4 had little to no suppression of p-ERK activity upon cerdulatinib treatment (Figure 8D). These results are similar to those observed in cell lines (Figure 7) suggesting individual patient samples may rely upon different signaling pathways. Interestingly, a significant linear correlation was found between the degree of p-ERK inhibition and the extent of cell death response (Figure 8E, left, $p=0.0117$ ). Meanwhile, no significant linear correlation was identified between the extent of p-AKT inhibition and the cell death response (Figure 8F, right, $p=0.2142$ ). The results suggest that indirect inhibition of downstream ERK phosphorylation by cerdulatinib may play a role in the final cellular outcome, and ERK inhibition may mediate the therapeutic effects of cerdulatinib.

\section{DISCUSSION}

Available clinical data indicate that BCR-directed inhibitors such as SYK (fostmatinib), BTK (ibrutinib) and PKC $\beta$ (enzastaurin) are active in $\leq 20 \%$ of DLBCL patients. This highlights the need to continue exploring novel agents with expanded activities in this disease. In this study, we first demonstrated the presence of active SYK and JAK in their phosphorylated forms in a significant fraction of DLBCL primary tumor tissues and cell lines. We then showed that cerdulatinib, a potent inhibitor of SYK and JAK, has broad anti-tumor activity as demonstrated by inhibition of 1) cellular metabolic function, 2) cell viability, 3) cell cycling, 4) signal transduction through SYK-PLC $\gamma 2-A K T$ or ERK, and 5) signal transduction through JAK-STAT. We further demonstrated that cerdulatinib induced cell death in primary DLBCL cells and the degree of cell death significantly correlated with decreased p-ERK.

While the broad activity of cerdulatinib in DLBCL cell lines may be ascribed to mechanisms beyond SYK and JAK inhibition (Table 1), the data presented herein with DLBCL cell lines and primary tumors are at least consistent with the hypothesis that SYK and JAK inhibition contributes to the antitumor activities of the drug. Target selectivity of cerdulatinib was demonstrated previously in different cell types of normal human whole blood as well. The compound potently inhibit BCR and FcR-induced SYK activation and cytokine receptorinduced JAK1/3 and JAK1/TYK2 activation in B cells, $\mathrm{T}$ cells and monocytes while it does not inhibit protein kinase C-mediated PMA signaling or LCK and ZAP70 mediated $\mathrm{T}$ cell antigen receptor signaling, or JAK2mediated GM-CSF signaling. [26]

Cerdulatinib demonstrated broader anti-tumor activity relative to several BCR-specific inhibitors we have evaluated. Previously, we have shown that dasatinib (targets mainly SRC family kinases at low concentrations) and PRT318 (highly specific for SYK) exert anti-tumor activity primarily by affecting cell cycle with minimal impact on cell viability $[12,13]$. However, with cerdulatinib, we observed apoptosis induction in addition to cell cycle inhibition (Figures 4-6) although the specific cellular effect varied from cell line to cell line. These data suggest that simultaneous inhibition of multiple therapeutically relevant targets, such as combined SYK and JAK, may represent a more effective approach compared to single target-directed agent.

It is also noteworthy that many cell lines resistant to BCR-targeted inhibitors were sensitive to cerdulatinib. Among the cell lines studied, LY3 carries an activating mutation in CARD11 [31] (Supplemental Table 2); LY3, LY10, U2932 (ABC) along with LY8, VAL, and SUDHL2 (GCB) carry inactivating mutations or hemizygous deletion in TNFAIP3 (A20), which negatively regulates $\mathrm{NF} \kappa \mathrm{B}$ activity. Loss of $A 20$ function results in constitutive activation of $\mathrm{NF \kappa B}$ that promotes tumor growth and survival. ABC cell lines, HBL1, LY3, LY10 and SUDHL2, along with GCB cell line SUDHL6 all carry activating MYD88 mutations, which promote IRAK1/4 and TRAF6 dimerization and subsequent $\mathrm{NF} \kappa \mathrm{B}$ activation.

The ultimate activation of $\mathrm{NF \kappa B}$, resulting from these BCR-associated or MYD88 mutations, leads to increased IL6 and IL10 autocrine secretion that subsequently activates JAK-STAT3 pathway to enhance cell survival and proliferation. This perhaps represents one of several mechanisms rendering tumor cells resistant to inhibitors of early BCR components. As a matter of fact, high levels of baseline phosphorylated STAT3 exhibited in the ABC cell lines (Figure 2) may be a result of the BCR/MYD88 mutations they carry. Cerdulatinib, with its ability to inhibit p-STAT3 in both cell lines and primary tumors, provides another point of blockade after $\mathrm{NF} \kappa \mathrm{B}$ activation. Antitumor activities were achieved by cerdulatinib in all cell lines carrying mutations including ABC cell lines HBL1 (MYD88), LY3 (CARD11, A20 and MYD88), LY10 (A20 and MYD88), SUDHL2 (A20 and MYD88), and U2932 (A20) as well as GCB cell lines LY8 

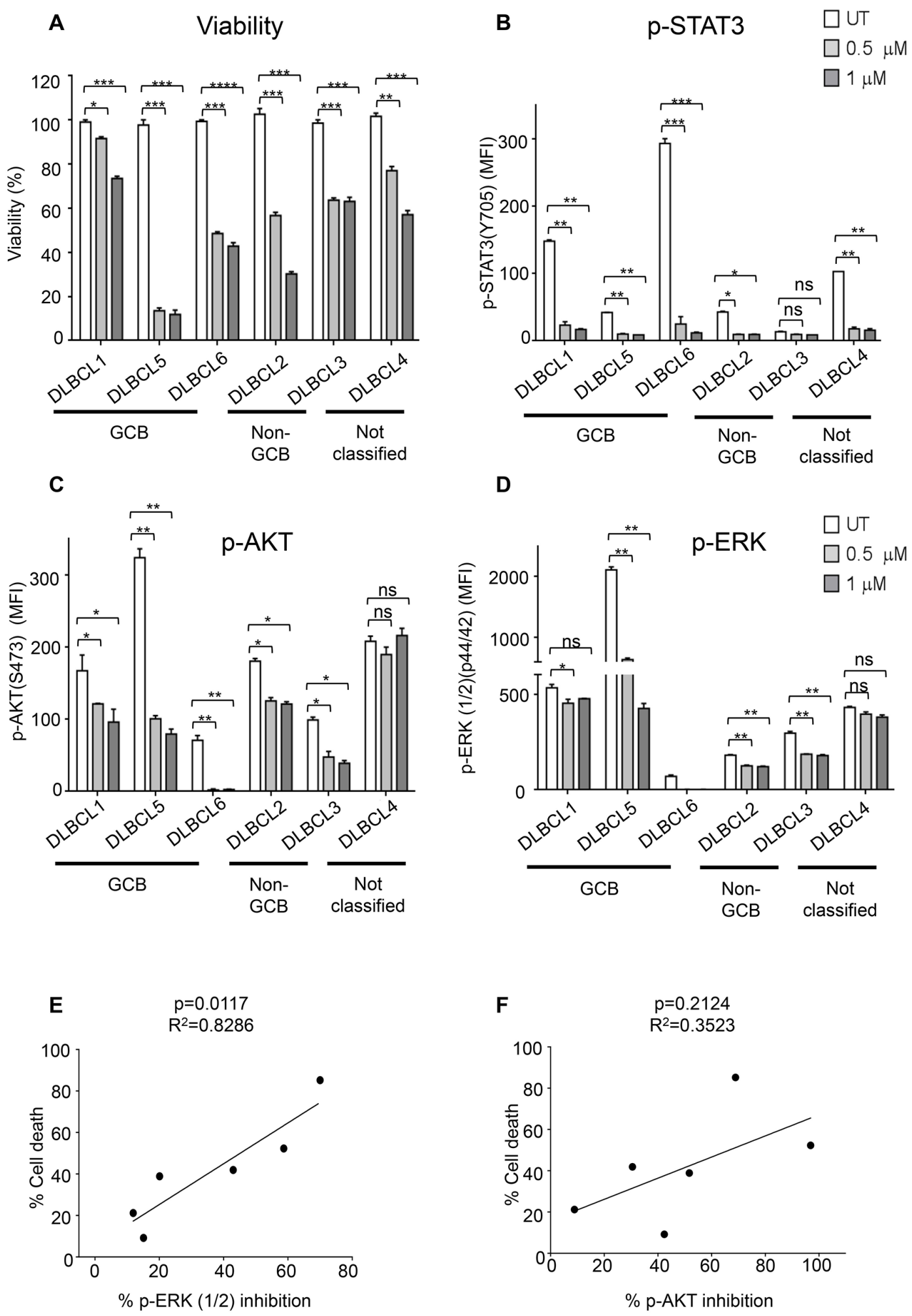

Figure 8: Primary DLBCL cells are sensitive to dual SYK/JAK inhibition. A. Six primary human DLBCL samples were treated with $0.5 \mu \mathrm{M}$ or $1 \mu \mathrm{M}$ cerdulatinib for $72 \mathrm{~h}$. Cell viability was measured by MTT assay, and normalized to vehicle control. Primary human DLBCL samples were treated with $0.5 \mu \mathrm{M}$ or $1 \mu \mathrm{M}$ cerdulatinib for $6 \mathrm{~h}$ followed by stimulation with $5 \mu \mathrm{g} / \mathrm{ml} \mathrm{IgM} / \mathrm{IgG}$ for $15 \mathrm{~min}$ at $37^{\circ} \mathrm{C}$. Phospho-flow assays were performed to determine the levels of p-STAT3 in $\mathbf{B}, \mathrm{p}$-AKT in $\mathbf{C}$ and p-ERK in $\mathbf{D}$ in the primary cells. Error bars represent the SEM from three independent experiments. ${ }^{*} p<0.05,{ }^{* *} p<0.01,{ }^{* * *} p<0.001,{ }^{* * * *} p<0.0001$. E. Relationship between cell death following treatment with $1 \mu \mathrm{M}$ cerdulatinib and percent inhibition of ERK1/2 was analyzed by Spearman correlation. F. Relationship between cell death and percentage of inhibition of AKT was statistically analyzed using one-way ANOVA test. Percent inhibition of phosphorylation was calculated using the formula: $\left[\left(\mathrm{MFI}_{\text {untreated }}-\mathrm{MFI}_{\text {treated }}\right) / \mathrm{MFI}_{\text {untreated }}\right] \times 100 \%$. 
(A20), SUDHL6 (MYD88) and VAL (A20) (Supplemental Table 2), likely by blocking the up-regulation of STAT3 activity induced by the sequential events of BCR/MYD88 mutations - NF- $\mathrm{KB}$ activation-cytokine release-JAK/ STAT. In particular, not only high levels of baseline phosphorylated STAT3 exhibited in the ABC cell lines render these cells very sensitive to cerdulatinib inhibition, but also cytokine-induced STAT3 phosphorylation in GCB cell lines (Figure 7B). Notably, some of these cell lines, LY3 in particular, was shown to be highly resistant to inhibition of SRC, SYK and BTK [10]. In the clinical trial setting, patients with mutations in CARD11, A20 and MYD88 indeed demonstrated resistance to ibrutinib, a BTK inhibitor [17]. In addition to BCR inhibitorresistant DLBCL, cerdulatinib (PRT2070) also has the capability to overcome ibrutinib resistance in CLL cells carrying $\mathrm{BTK}^{\mathrm{C} 481 \mathrm{~S}}$ mutation $[28,29]$. These data suggest that simultaneous inhibition of multiple therapeutically relevant targets, such as combined SYK and JAK, may represent a more effective approach for the treatment of B-cell lymphoma.

\section{MATERIALS AND METHODS}

\section{Cell lines, primary cells and culture conditions}

GCB cell lines OCI-LY1, OCI-LY4, OCI-LY8, OCI-LY18, SUDHL6 and VAL were cultured in Iscove's Modified Dulbecco's Medium (IMDM) supplemented with $20 \%$ Fetal Bovine Serum (FBS) and $100 \mu \mathrm{g} / \mathrm{mL}$ penicillin/streptomycin. ABC cell lines SUDHL2 and HBL1 were cultured in RPMI1640 supplemented with $20 \% \mathrm{FBS}$ and $100 \mu \mathrm{g} / \mathrm{mL}$ penicillin/streptomycin. OCILY3 cells were grown in RPMI1640 supplemented with $20 \%$ FBS, $100 \mu \mathrm{g} / \mathrm{ml}$ penicillin/streptomycin and HEPES. ABC cell lines OCI-LY10 was cultured in Iscove's Modified Dulbecco's Medium (IMDM) supplemented with $20 \%$ human serum and $100 \mu \mathrm{g} /$ $\mathrm{mL}$ penicillin/streptomycin. ABC cell line U2932 was cultured in high glucose RPMI1640 supplemented with $20 \% \mathrm{FBS}, 100 \mu \mathrm{g} / \mathrm{ml}$ penicillin/streptomycin. All cells were maintained in a humidified $37^{\circ} \mathrm{C} / 5 \%$ $\mathrm{CO}_{2}$ incubator. Frozen primary DLBCL cells were obtained from the tumor bank of the Department of Pathology at Weill Cornell Medical College after Institutional Review Board review and approval. All primary cells were thawed as previously described [32] and cultured in above conditions at $37^{\circ} \mathrm{C}$ for $6 \mathrm{~h}$ in the presence or absence of cerdulatinib followed by BCR stimulations with $5 \mu \mathrm{g} / \mathrm{mL}$ of IgM and IgG. The clinical characteristics of these patients are listed in the Supplemental Table 1. Cerdulatinib [26] was kindly provided by Portola Pharmaceuticals Inc. (South San Francisco, CA) and stored as $10 \mathrm{mM}$ stock at $-20^{\circ} \mathrm{C}$.

\section{Immunohistochemistry}

The study included 62 DLBCL samples in two tissue microarrays from 2000-2011. Twenty-five cases were from nodal sites and 37 from extranodal sites. Only tumors with enough tissues were included. Immunohistochemical stains of p-STAT3 (Y705, rabbit monoclonal Ab, clone D3A7, Cell Signaling) and p-SYK (Y525/526; rabbit polyclonal Ab; Cell Signaling) were performed and the results were evaluated by proportion of lymphoma cells that were stained. The antibody reactivity in $\geq 30 \%$ of the lymphoma cells was considered positive. Paraffinembedded normal tonsil tissue was included as a baseline expression level for $\mathrm{p}$-STAT3 and p-SYK.

\section{Immunoblotting assays and antibodies}

Immunoblotting were performed as previously described [32]. Antibodies including total STAT3, SYK, PLC $\gamma 2$, AKT, ERK1/2, PARP, caspase 3, and phosphorylated STAT3 (S727), STAT3 (Y705), SYK (Y525/526), PLC $\gamma 2$ (Y759), PLC 22 (Y1217), AKT (S473), ERK1/2 (Y204) and RB (S807/811) were purchased from Cell Signaling (Danvers, MA). Cyclin E antibody was purchased from Santa Cruz Biotechnology (Dallas, TX), and $\beta$-actin antibody was purchased from Sigma-Aldrich (St Louis, MO). Antibodies used in phosphoflow assay, including phosphorylated STAT3 (S727), SYK (Y525/526), PLC 22 (Y759), AKT (S473), and ERK1/2 (Y204) were purchased from BD Biosciences (San Jose, CA).

\section{Cell metabolic activity, cell growth and viability determination}

DLBCL cell lines were treated with various concentrations of cerdulatinib for up to $72 \mathrm{~h}$. The metabolic activities of cells were determined with MTT assay according to manufacturer's instruction (Roche Applied Science, Indianapolis, IN) at $72 \mathrm{~h}$ time point. $\mathrm{IC}_{50}$ was calculated using the Sigma Plot generated with GraphPad Prism 6 software (GraphPad, La Jolla, CA). Cell growth was measured at every $24 \mathrm{~h}$ counting live cells with flow cytometry as previously described [12]. Cells were collected every $24 \mathrm{~h}$ and cell viability was determined by the PE Annexin V Apoptosis Detection Kit I (BD Biosciences).

\section{Cell cycle analysis}

DLBCL cells were treated with various concentrations of cerdulatinib for $48 \mathrm{~h}$. Cells were incubated with $10 \mu \mathrm{M}$ BrdU (BD Biosciences, San Jose, CA) at $37^{\circ} \mathrm{C}$ for $2 \mathrm{~h}$, and stained with PE conjugated anti-BrdU antibody (BD Biosciences) according to the supplier's manual. The percentage of cell cycle distribution was analyzed with FlowJo (Tree Star Inc. Ashland, OR). 


\section{Intracellular phosphospecific flow cytometry assays}

DLBCL cells were treated with cerdulatinib for 6 $\mathrm{h}$ followed by stimulation with $5 \mu \mathrm{g} / \mathrm{mL}$ of goat $\mathrm{F}$ (ab')2 anti-human IgM and IgG antibodies (Southern Biotech, Birmingham, AL) at $37^{\circ} \mathrm{C}$ for $15 \mathrm{~min}$. Cells were fixed in $4 \%$ formaldehyde at room temperature for $10 \mathrm{~min}$, and permeabilized with $100 \%$ methanol on ice for $20 \mathrm{~min}$ before flow cytometric analyses.

\section{Statistical analyses}

A One-way ANOVA test was performed to compare the percentage of $\mathrm{S}$ phase distribution or the MFI fold changes between the treated and untreated DLBCL cell lines/primary cells. The relationships between the percentage of cell death response and inhibition of ERK1/2 or AKT phosphorylation were analyzed by Spearman correlation

\section{CONFLICTS OF INTEREST}

GC, AP and PC are employees of Portola Pharmaceuticals, Inc. The research was partially sponsored through a research grant from Portola. There are no other competing financial interests to declare.

\section{Authors' contributions}

YLW and GC formed the hypothesis. JM developed the assays, designed and performed the experiments, solved technical problems, analyzed the data and wrote part of the manuscript; WX, KD, KL, AL, GR, HY performed some experiments and analyzed the data; $\mathrm{GC}$, $\mathrm{AP}$ and $\mathrm{PC}$ contributed useful discussions and suggestions. YLW directed and coordinated the project designed the experiments, analyzed the data and wrote the manuscript.

\section{REFERENCES}

1. Dal Porto JM, Gauld SB, Merrell KT, Mills D, PughBernard AE and Cambier J. B cell antigen receptor signaling 101. Molecular immunology. 2004; 41:599-613.

2. Alizadeh AA, Eisen MB, Davis RE, Ma C, Lossos IS, Rosenwald A, Boldrick JC, Sabet H, Tran T, Yu X, Powell JI, Yang L, Marti GE, Moore T, Hudson J, Jr., Lu L, et al. Distinct types of diffuse large B-cell lymphoma identified by gene expression profiling. Nature. 2000; 403:503-511.

3. Rosenwald A, Wright G, Chan WC, Connors JM, Campo E, Fisher RI, Gascoyne RD, Muller-Hermelink HK, Smeland EB, Giltnane JM, Hurt EM, Zhao H, Averett L, Yang L, Wilson WH, Jaffe ES, et al. The use of molecular profiling to predict survival after chemotherapy for diffuse largeB-cell lymphoma. The New England journal of medicine. 2002; 346:1937-1947.
4. Wright G, Tan B, Rosenwald A, Hurt EH, Wiestner A and Staudt LM. A gene expression-based method to diagnose clinically distinct subgroups of diffuse large B cell lymphoma. Proceedings of the National Academy of Sciences of the United States of America. 2003; 100:9991-9996.

5. Rosenwald A, Wright G, Leroy K, Yu X, Gaulard P, Gascoyne RD, Chan WC, Zhao T, Haioun C, Greiner TC, Weisenburger DD, Lynch JC, Vose J, Armitage JO, Smeland EB, Kvaloy S, et al. Molecular diagnosis of primary mediastinal B cell lymphoma identifies a clinically favorable subgroup of diffuse large B cell lymphoma related to Hodgkin lymphoma. The Journal of experimental medicine. 2003; 198:851-862.

6. Roschewski M, Staudt LM and Wilson WH. Diffuse large B-cell lymphoma-treatment approaches in the molecular era. Nature reviews Clinical oncology. 2014; 11:12-23.

7. Davis RE, Brown KD, Siebenlist $U$ and Staudt LM. Constitutive nuclear factor kappaB activity is required for survival of activated B cell-like diffuse large B cell lymphoma cells. The Journal of experimental medicine. 2001; 194:1861-1874.

8. Compagno M, Lim WK, Grunn A, Nandula SV, Brahmachary M, Shen Q, Bertoni F, Ponzoni M, Scandurra M, Califano A, Bhagat G, Chadburn A, Dalla-Favera R and Pasqualucci L. Mutations of multiple genes cause deregulation of NF-kappaB in diffuse large B-cell lymphoma. Nature. 2009; 459:717-721.

9. Monti S, Savage KJ, Kutok JL, Feuerhake F, Kurtin P, Mihm M, Wu B, Pasqualucci L, Neuberg D, Aguiar RC, Dal Cin P, Ladd C, Pinkus GS, Salles G, Harris NL, DallaFavera R, et al. Molecular profiling of diffuse large B-cell lymphoma identifies robust subtypes including one characterized by host inflammatory response. Blood. 2005; 105:1851-1861.

10. Davis RE, Ngo VN, Lenz G, Tolar P, Young RM, Romesser PB, Kohlhammer H, Lamy L, Zhao H, Yang Y, Xu W, Shaffer AL, Wright G, Xiao W, Powell J, Jiang JK, et al. Chronic active B-cell-receptor signalling in diffuse large B-cell lymphoma. Nature. 2010; 463:88-92.

11. Chen L, Monti S, Juszczynski P, Daley J, Chen W, Witzig TE, Habermann TM, Kutok JL and Shipp MA. SYKdependent tonic B-cell receptor signaling is a rational treatment target in diffuse large B-cell lymphoma. Blood. 2008; 111:2230-2237.

12. Yang C, Lu P, Lee FY, Chadburn A, Barrientos JC, Leonard JP, Ye F, Zhang D, Knowles DM and Wang YL. Tyrosine kinase inhibition in diffuse large B-cell lymphoma: molecular basis for antitumor activity and drug resistance of dasatinib. Leukemia. 2008; 22:1755-1766.

13. Cheng S, Coffey G, Zhang XH, Shaknovich R, Song Z, Lu P, Pandey A, Melnick AM, Sinha U and Wang YL. SYK inhibition and response prediction in diffuse large B-cell lymphoma. Blood. 2011; 118:6342-6352.

14. Chen L, Monti S, Juszczynski P, Ouyang J, Chapuy B, Neuberg D, Doench JG, Bogusz AM, Habermann TM, 
Dogan A, Witzig TE, Kutok JL, Rodig SJ, Golub T and Shipp MA. SYK inhibition modulates distinct PI3K/AKTdependent survival pathways and cholesterol biosynthesis in diffuse large B cell lymphomas. Cancer cell. 2013; 23:826-838

15. Friedberg JW, Sharman J, Sweetenham J, Johnston PB, Vose JM, Lacasce A, Schaefer-Cutillo J, De Vos S, Sinha R, Leonard JP, Cripe LD, Gregory SA, Sterba MP, Lowe AM, Levy R and Shipp MA. Inhibition of Syk with fostamatinib disodium has significant clinical activity in nonHodgkin lymphoma and chronic lymphocytic leukemia. Blood. 2010; 115:2578-2585.

16. Robertson MJ, Kahl BS, Vose JM, de Vos S, Laughlin M, Flynn PJ, Rowland K, Cruz JC, Goldberg SL, Musib L, Darstein C, Enas N, Kutok JL, Aster JC, Neuberg D, Savage $\mathrm{KJ}$, et al. Phase II study of enzastaurin, a protein kinase C beta inhibitor, in patients with relapsed or refractory diffuse large B-cell lymphoma. Journal of clinical oncology : official journal of the American Society of Clinical Oncology. 2007; 25:1741-1746.

17. Wilson WH, Young RM, Schmitz R, Yang Y, Pittaluga S, Wright G, Lih CJ, Williams PM, Shaffer AL, Gerecitano J, de Vos S, Goy A, Kenkre VP, Barr PM, Blum KA, Shustov A, et al. Targeting B cell receptor signaling with ibrutinib in diffuse large B cell lymphoma. Nat Med. 2015; 21:922-926.

18. Lam LT, Wright G, Davis RE, Lenz G, Farinha P, Dang L, Chan JW, Rosenwald A, Gascoyne RD and Staudt LM. Cooperative signaling through the signal transducer and activator of transcription 3 and nuclear factor-\{kappa\}B pathways in subtypes of diffuse large B-cell lymphoma. Blood. 2008; 111:3701-3713.

19. Ngo VN, Young RM, Schmitz R, Jhavar S, Xiao W, Lim KH, Kohlhammer H, Xu W, Yang Y, Zhao H, Shaffer AL, Romesser P, Wright G, Powell J, Rosenwald A, MullerHermelink HK, et al. Oncogenically active MYD88 mutations in human lymphoma. Nature. 2011; 470:115-119.

20. Gascoyne RDS, C. VII. The role of the microenvironment in lymphoid cancers. Annals of Oncology. 2011; 22: iv47-iv50.

21. Scott DW and Gascoyne RD. The tumour microenvironment in B cell lymphomas. Nat Rev Cancer. 2014; 14:517-534.

22. Huang X, Meng B, Iqbal J, Ding BB, Perry AM, Cao W, Smith LM, Bi C, Jiang C, Greiner TC, Weisenburger DD, Rimsza L, Rosenwald A, Ott G, Delabie J, Campo E, et al. Activation of the STAT3 signaling pathway is associated with poor survival in diffuse large B-cell lymphoma treated with R-CHOP. Journal of clinical oncology : official journal of the American Society of Clinical Oncology. 2013; 31:4520-4528.

23. Ding BB, Yu JJ, Yu RY, Mendez LM, Shaknovich R, Zhang Y, Cattoretti G and Ye BH. Constitutively activated STAT3 promotes cell proliferation and survival in the activated B-cell subtype of diffuse large B-cell lymphomas. Blood. 2008; 111:1515-1523.

24. Younes A, Romaguera J, Fanale M, McLaughlin P, Hagemeister F, Copeland A, Neelapu S, Kwak L, Shah J, de Castro Faria S, Hart S, Wood J, Jayaraman R, Ethirajulu $\mathrm{K}$ and Zhu J. Phase I study of a novel oral Janus kinase 2 inhibitor, SB1518, in patients with relapsed lymphoma: evidence of clinical and biologic activity in multiple lymphoma subtypes. Journal of clinical oncology : official journal of the American Society of Clinical Oncology. 2012; 30:4161-4167.

25. Kurzrock R, Voorhees PM, Casper C, Furman RR, Fayad L, Lonial S, Borghaei H, Jagannath S, Sokol L, Usmani SZ, van de Velde H, Qin X, Puchalski TA, Hall B, Reddy M, Qi M, et al. A phase I, open-label study of siltuximab, an anti-IL-6 monoclonal antibody, in patients with B-cell non-Hodgkin lymphoma, multiple myeloma, or Castleman disease. Clinical cancer research : an official journal of the American Association for Cancer Research. 2013; 19:3659-3670.

26. Coffey G, Betz A, DeGuzman F, Pak Y, Inagaki M, Baker DC, Hollenbach SJ, Pandey A and Sinha U. The novel kinase inhibitor PRT062070 (Cerdulatinib) demonstrates efficacy in models of autoimmunity and B-cell cancer. J Pharmacol Exp Ther. 2014; 351:538-548.

27. Cheng S, Ma J, Guo A, Lu P, Leonard JP, Coleman M, Liu M, Buggy JJ, Furman RR and Wang YL. BTK inhibition targets in vivo CLL proliferation through its effects on B-cell receptor signaling activity. Leukemia. 2014; 28:649-657.

28. Furman RR, Cheng S, Lu P, Setty M, Perez AR, Guo A, Racchumi J, Xu G, Wu H, Ma J, Steggerda SM, Coleman $\mathrm{M}$, Leslie $\mathrm{C}$ and Wang YL. Ibrutinib resistance in chronic lymphocytic leukemia. The New England journal of medicine. 2014; 370:2352-2354.

29. Cheng S, Guo A, Lu P, Ma J, Coleman M and Wang YL. Functional characterization of BTK mutation that confers ibrutinib resistance: exploration of alternative kinase inhibitors. Leukemia. 2015; 29:895-900.

30. Hans CP, Weisenburger DD, Greiner TC, Gascoyne RD, Delabie J, Ott G, Muller-Hermelink HK, Campo E, Braziel RM, Jaffe ES, Pan Z, Farinha P, Smith LM, Falini $\mathrm{B}$, Banham AH, Rosenwald A, et al. Confirmation of the molecular classification of diffuse large B-cell lymphoma by immunohistochemistry using a tissue microarray. Blood. 2004; 103:275-282.

31. Pasqualucci L, Trifonov V, Fabbri G, Ma J, Rossi D, Chiarenza A, Wells VA, Grunn A, Messina M, Elliot O, Chan J, Bhagat G, Chadburn A, Gaidano G, Mullighan CG, Rabadan R, et al. Analysis of the coding genome of diffuse large B-cell lymphoma. Nature genetics. 2011; 43:830-837.

32. Ma J, Lu P, Guo A, Cheng S, Zong H, Martin P, Coleman $\mathrm{M}$ and Wang YL. Characterization of ibrutinib-sensitive and -resistant mantle lymphoma cells. British journal of haematology. 2014; 166:849-861. 